\title{
Fisheries Restrictions and Their Cascading Effects on Herbivore Abundance and Macroalgae Removal at Kenyan Coral Reefs
}

Ewout Geerten Knoester ( $\nabla$ ewout.knoester@wur.nl)

Wageningen University \& Research https://orcid.org/0000-0002-5502-5569

Veerle Eline Plug

Kenyatta University

AJ Murk

Wageningen University

Susan Okoth Sande

Kenyatta University

Ronald Osinga

Wageningen University

Research Article

Keywords: Browsers, Padina, Sargassum, Protected area, Grazers, Restoration

Posted Date: January 31st, 2022

DOI: https://doi.org/10.21203/rs.3.rs-1299899/v1

License: (c) (1) This work is licensed under a Creative Commons Attribution 4.0 International License. Read Full License 


\section{Abstract}

The increase of macroalgae at degraded reefs impedes ecosystem services and calls for effective methods to facilitate a return to coral dominance. Removal of macroalgae (i.e. browsing) is typically realized by fish, but the role and identity of browsers at the heavily-fished East African Coast is still largely unknown. This study investigated how browsing pressure at Kenyan reefs $(-4.700,39.396)$ related to fisheries management and herbivore abundance. From October 2018 to January 2019, consumption during 24-h buffet assays using the brown macroalgae Sargassum and Padina was determined and video recorded at six sites: two in fished zones, two in marine reserves (traditional fishing allowed) and two in no-take zones. Herbivorous fish composition and biomass and urchin abundance were also determined. Consumption of both Sargassum and Padina was significantly lower in the fished zones ( $25 \%$ and $27 \%$ of macroalgal biomass consumed, respectively) compared to the no-take zones ( $66 \%$ and $81 \%$ ), with intermediate consumption in the marine reserves ( $49 \%$ and $73 \%$ ). Biomasses of herbivorous fish (browsers, grazers and scrapers) were between 3 to 30 times higher in the protected zones, whereas sea urchins and territorial damselfish were more abundant in fished zones. Macroalgae consumption correlated positively with the biomass of browsing and grazing fish and negatively with sea urchin abundance. Fish from various functional groups were identified as dominant browsers and these differed strongly across sites. These results indicate that fishing restrictions are likely to support reef resilience by increasing herbivorous fish biomass of key species and thereby promote macroalgae removal.

\section{Introduction}

Important ecosystem services such as coastal protection and sustainable fisheries provision become reduced when coral reefs degrade into seascapes dominated by macroalgae (Pratchett et al. 2014; Rogers et al. 2018). Herbivores, especially fish, play a crucial role in promoting coral over macroalgal dominance either by preventing the establishment of macroalgal recruits through continuous removal of algal turf (i.e. grazing) or by reversing macroalgal dominance through selective removal of mature macroalgae (i.e. browsing). Grazing of algal turf creates favourable conditions for coral growth and settlement and thereby supports coral dominance (Lefcheck et al. 2019) and consequently reef biodiversity and resilience (Nyström et al. 2008). However, with climate change-induced temperature stress weakening the competitive potential of corals (Sully et al. 2019) in combination with overfishing (McCauley et al. 2015) and eutrophication (Norström et al. 2009), the impaired grazer community becomes increasingly unable to prevent macroalgae establishment. First observed in the Caribbean (Hughes 1994), coral to macroalgae phase shifts are now repeatedly reported from Indo-Pacific reefs as well (Ledlie et al. 2007). Once established, macroalgae prevent a return to a coral-dominated state by supressing the survival, fecundity and recruitment of corals (Hughes et al. 2007; Schmitt et al. 2019). It is only through the active removal of macroalgae by browsers that reversal of such phase shifts can likely be achieved (Puk et al. 2016). Therefore, a good understanding on the distribution of key browsing species and the factors influencing their potential to control macroalgae is important. 
The use of functional groups has proven helpful to understand the principles of ecological processes and coral reef resilience (Heenan and Williams 2013). Even though herbivory is a well-studied process on coral reefs, research focussed on browsers specifically has been challenging and full of surprises. Identification of key species responsible for macroalgae removal based on their abundance only has remained precarious (Puk et al. 2016) and therefore browser biomass estimates alone remain inadequate as an indicator for reef resilience (Nyström et al. 2008; Brandl and Bellwood 2014). Due to the cautious nature of browsers, biomass estimates from visual surveys tend to underestimate browser diversity and biomass (Hoey and Bellwood 2010; Michael et al. 2013) and the use of video-recorded macroalgae buffet assays have provided a wealth of additional information on browsers (Bennett and Bellwood 2011). Browsing on macroalgae seems to be commonly done by a small subset of the diverse browser community due to spatial, temporal and behavioural variation (Bennett and Bellwood 2011; Lefèvre and Bellwood 2011; Puk et al. 2016), and is sometimes dominated by species traditionally not considered as browsers (Bellwood et al. 2006; Chong-Seng et al. 2014; Tebbett et al. 2020). In addition to these various groups of fish, sea urchins can also contribute to the control of macroalgae (McClanahan et al. 1994) and this has been especially important for Caribbean reefs (Francis et al. 2019). At certain overfished Indo-Pacific reefs increasing numbers of sea urchins have become more dominant in macroalgal control (Humphries et al. 2014), but also contribute heavily to reef erosion through their scraping feeding method (Norström et al. 2009). In short, the identity and impact of browser communities appear variable across broad ranges but also between reefs with apparent plasticity in functional roles, making it difficult to predict browsing function from biomass estimates alone.

Mismatches between abundance and ecological relevance of browser species have important management implications, where protection of certain species might not result in the desired coral reef resilience (McClanahan 2008). A good understanding on which species contribute most to macroalgae removal can enable managers to increase reef resilience and the likelihood of phase shift reversal when restoration towards coral dominance is desired (Ladd et al. 2018). Although several studies on the wellprotected Great Barrier Reef have proven invaluable to identify dominant browsers and potential drivers for the regional variability in browsing pressure (Hoey and Bellwood 2009; Bennett and Bellwood 2011; Michael et al. 2013; Streit et al. 2015), the application of this knowledge to other geographical areas and sites with higher fishing pressure may be limited. Indeed, superimposed on geographic differences (Heenan et al. 2016) is the divergent fishing pressure among coastal populations, in which large-bodied fishes such as browsers are preferred targets (Plass-Johnson et al. 2015). The high susceptibility of browsers to fishing pressure and their important yet complex role in the coral-algae balance call for a better understanding of these dynamics in general and variability among geographical areas in particular.

This study aimed to further improve our understanding on browsing by expanding the geographic scope and including the impact of fisheries management within the study domain. We provide an identification of key browsers and quantification of their browsing capacity at six Kenyan reefs, which form part of a mostly intensely-utilized and understudied fringing reef in the Western Indian Ocean. Here, the enforcement of three distinct fisheries management zones (open access fished zone, marine reserve for traditional fishing only and a well-enforced no-take zone) are well suited to investigate the impact of 
management on the browser community and their influence on reef resilience. We hypothesise that increasing levels of fisheries restrictions will increase herbivorous fish biomass and result in more effective control of macroalgae. Through video-recorded macroalgae buffet assays we identified key browsing species and their browsing pressure and compared this with biomass estimates from stationary fish surveys and sea urchin counts. Lastly, we used benthic surveys to investigate how two commonlyused reef condition indicators (coral cover and macroalgal cover) relate to the browser community and their consumption of macroalgae to allow for a perspective on reef resilience.

\section{Materials And Methods}

\section{Study sites}

The study was performed around Wasini Island in southern Kenya from October 2018 till January 2019 during the dry northeast monsoon. Tidal differences in the area are significant, reaching over four meters during spring tide. Six study sites were chosen (Fig. 1), equally distributed over areas subjected to three fisheries management types. Two study sites are located in an unrestricted fished zone, where intense and unselective fishing is performed daily by artisanal fishermen using mainly traps, nets, spearguns and hook and line (sites 1 and 2). Two study sites are in the Mpunguti Marine Reserve $\left(11 \mathrm{~km}^{2}\right.$ established in 1973), where only traditional fishing methods are allowed (i.e. traps and hook and line) and this is enforced by the Kenyan Wildlife Service (sites 3 and 4). Two well-enforced no-take zones were chosen to complete the comparison, each with one study site: Kisite Marine National Park ( $28 \mathrm{~km}^{2}$ established in 1973) enforced by the Kenya Wildlife Service (site 5), and the Wasini Community Managed Area (0.31 $\mathrm{km}^{2}$ established in 2008) enforced locally by the Wasini Beach Management Unit (site 6). Sites 1, 2 and 6 are situated in a sea strait between Wasini Island and the mainland and experience relatively turbid water conditions (average visibility $\sim 7$ meters) and therefore exhibit a shallow (up to 8 meters depth) and patchy reef development. Sites 3, 4 and 5, south of Wasini Island, are further offshore and have an average visibility of $\sim 15$ meters and fringing reef development up to around 16 meters depth.

\section{Benthic and fish surveys}

A 20-m point intercept transect with $0.5 \mathrm{~m}$ interval was used to map benthic cover in broad categories (hard coral, soft coral, turf algae $(<1 \mathrm{~cm})$, fleshy macroalgae $(>1 \mathrm{~cm})$ and a pooled category 'other' including mainly sand, rubble and uncommon invertebrates such as sponges and tunicates (Hill and Wilkinson 2004). Within a $2 \times 20 \mathrm{~m}^{2}$ belt transect sea urchins were identified to species level and counted to determine their abundance (Hill and Wilkinson 2004). A stationary fish census (radius of $7.5 \mathrm{~m}$ ) was used to quantify the composition and abundance of all diurnal, non-cryptic fish (Bohnsack and Bannerot 1986). Fish sizes (fork length) were estimated in classes of $5 \mathrm{~cm}$ for fishes smaller than $20 \mathrm{~cm}$, and in 10$\mathrm{cm}$ size classes for larger individuals. Per study site, 10 replicate benthic surveys and $11-15$ replicate fish surveys were performed.

\section{Macroalgae buffet assay}


At each study site, browsing pressure was determined by recording consumption from macroalgae buffet assays over $24 \mathrm{~h}$ (Fig. 2). Two brown macroalgae were used: Sargassum ilicifolium and Padina boergesenii (henceforth referred to by genus name only). These brown algae were chosen as they are the dominant macroalgae in the area and are typical representatives of algal climax communities (Humphries et al. 2014). One day before use, the macroalgae were collected from the shallow reef flat at study site 1 and stored in seawater basins. Before and after deployment, the drip-dry wet weight (shaken 10 times to remove excess water) of each macroalgae was determined. The macroalgae were kept in their natural growth form, resulting in the following average starting weights (mean \pm SD): Sargassum $(38.3 \pm 4.6 \mathrm{~g})$ and Padina $(18.4 \pm 2.9 \mathrm{~g})$. The buffet assay also included the seagrass Thalassia hemprichii to allow for comparisons with an older buffet assay study from the Kenyan coast (McClanahan 2008), but these results are discussed separately in the supplementary materials (Fig. S1)

as the focus of this report is on macroalgae. For deployment, the three different macrophyte species were strung equidistant and in random order on a 1-m fishing line. The line was weighted with three 10-cm metal pins to enable secure placement on the reef substratum and to provide access to both vertebrate and invertebrate, bottom-dwelling browsers. The macrophytes were transported in basins with seawater and deployed at the reef slope of study sites with a fringing reef or on patch reefs at the other sites. One replicate buffet assay consisted of 10 lines, each line approximately separated 2 meters from the next. Per replicate assay, one additional control line was placed inside a weighted plastic cage of $30 \times 30 \times 50$ $\mathrm{cm}^{3}$ with $1.3 \times 1.3 \mathrm{~cm}^{2}$ mesh size to exclude all macro-browsers and was used to check for weight loss due to handling, following Seah et al. (2021) amongst others. For each study site, the assays were repeated on five non-consecutive days throughout the 4-month study period.

\section{Remote underwater video}

To identify the species responsible for the reduction in macroalgae biomass and to quantify their browsing activity with minimum disturbance, the first 75 mins of deployment of each buffet assay was recorded on remote underwater video (RUV). A Canon 600D DSLR camera in a Neewer 40M case was placed on a weighted tripod, approximately 2 meters from one randomly chosen line. The camera was programmed to take 10-min clips, with a starting delay and interval of $5 \mathrm{~min}$, resulting in a total recording time of 45 min per assay. Recording took place between $1000 \mathrm{~h}$ and $1400 \mathrm{~h}$, which coincides with the peak in foraging activity of most roving (i.e. mobile) herbivorous fish (Hoey and Bellwood 2009). In total, 30 recordings were made.

\section{Data processing and analysis}

Data on benthic cover, fish composition, fish biomass and grazing sea urchin density is presented descriptively. Grazing sea urchins include all sea urchin species except two burrowing species (Echinometra mathaei and Echinostrephus molaris). Data from stationary visual surveys was used to estimate fish biomass using the midpoint of each size class and published length-weight relationships (Froese and Pauly 2015). Average herbivorous fish biomass was subdivided into the following functional groups: browsers, grazers, scrapers and excavators, based on reported species' functional traits following 
Green \& Bellwood (2009). Two additions were made: Platax spp. were also considered browsers (Bellwood et al. 2006) and territorial damselfish were considered as a separate functional group, including the common genera Amblyglyphidodon, Plectroglyphidodon and Stegastes.

The fraction consumption of buffet assays was calculated following Bennett \& Bellwood (2011): Consumption $(\mathrm{F})=1-\frac{M_{1}}{M_{0} *(1-C)}$ where $\mathrm{M}_{0}$ is the initial macroalgal mass, $\mathrm{M}_{1}$ the remaining mass after $24 \mathrm{~h}$ and $\mathrm{C}$ the mean fraction of biomass loss at the control treatment (calculated separately for each site and each macroalgae). The mean of 10 lines was taken for each replicate buffet assay and data analysis was performed in R (R Core Team 2020). A beta regression model with logit link was used to account for the proportional nature of the consumption data (Douma and Weedon 2019) using the glmmTMB package (Brooks et al. 2017). A mixed-effects model was built to determine the fixed effects of Protection (Fished, Reserve and No-take) and Species (Sargassum and Padina) on consumption. Study site and Assay were included as nested random factors to account for the non-independence of repeated measurements at each study site within protection zone and the non-independence of macrophyte species on the same line. The Wald Chi-Squared Test from the carpackage (Fox and Weisberg 2018) was used to determine the significance of the fixed factors and their interaction. Model assumptions were validated by visual inspection of DHARMa diagnostic plots for mixed regression models (Hartig 2021). Within-level differences between Protection for each Species were examined using pair-wise means comparisons with Tukey adjustment using the emmeans package (Lenth 2020).

All RUV recordings were viewed and for each bite the targeted macroalgae and involved fish species were noted. In addition, fish's fork length was estimated (using the buffet line as reference), transformed to weight using published length-weight relationships (Froese and Pauly 2015) and multiplied by the number of bites taken to calculate mass-scaled bites (ms-bites) following Hoey and Bellwood (2009). Sums of ms-bites were standardized to hour to correct for slight variations in RUV recording length. Bite impact estimated from RUV is thus expressed as ms-bites in $\mathrm{kg} \mathrm{h}^{-1}$.

Average macroalgae consumption per study site was correlated against the study site's average herbivorous fish biomass (browsers, grazers, scrapers, territorial damselfish and total), grazing sea urchin density, hard coral cover and macroalgal cover using Pearson's test. Macroalgae consumption was also specifically correlated against the biomass of unicornfish (Naso spp.) as these fish were identified as abundant and important browsers. Excavators were not included in these correlations because of their low numbers. Patterns were similar for both Sargassum and Padina and it was decided to pool the two macroalgae to aid visualisation and increase the low statistical power, but it should be noted that the two macroalgae were not independent of each other (presented on the same assay line). The correlations are thus mainly intended to explore broad patterns and conclusions drawn from them will be moderated accordingly.

\section{Results}




\section{Benthos and fish}

Average hard coral cover was relatively high across study sites with values ranging between $25-47 \%$, except at site 3 where only $6 \%$ hard coral cover was found (Fig. 1). In contrast, macroalgal cover was low for all sites $(<8 \%)$ except at site 3 where half of the substrate was covered by macroalgae (mainly Sargassum spp.). The density of grazing sea urchins (Fig. 1) was highest in the fished zones (0.8 and 1.1 sea urchins $\mathrm{m}^{-2}$ at sites 1 and 2 , respectively) and lower in the marine reserves and no-take zones $(<0.5$ sea urchins $\mathrm{m}^{2}$ at sites $3-6$ ). Total fish biomass was low in the fished zones and marine reserves, with values ranging between $150-285 \mathrm{~kg} \mathrm{ha}^{-1}$ for sites $1-4$ (Fig. 1). In the no-take zones, total fish biomass was much higher: $898 \mathrm{~kg} \mathrm{ha}^{-1}$ for site 5 and $1667 \mathrm{~kg} \mathrm{ha}^{-1}$ for site 6 . In line with total fish biomass, the biomass of herbivorous fish was highest in the no-take zones, but also site 4 in the marine reserve hosted a considerable biomass of herbivorous fish (Fig. 3). These higher herbivore biomasses were not only attributable to more herbivores being present, but also due to the presence of larger $(>30 \mathrm{~cm})$ individuals, which were completely absent from sites 1 - 3 (Fig. S2).

The composition of functional groups within the herbivorous fish community also differed between sites. Browsers were rarely seen at fished sites 1 and 2 or at site 3 in the marine reserve but made up between a third to more than half of the herbivorous fish community at site 4 in the marine reserve and in both notake zones (Fig. 3). Grazers made up about a third of the herbivorous fish community at most sites, except at site 2 where over two-thirds of the herbivores were grazers and site 6 where only a fifth were grazers. Scrapers and excavators were only regularly encountered in the no-take zones and made up slightly more than a third of the herbivorous fish community there. Territorial damselfish made up only a small proportion of the herbivorous fish biomass for all sites, except site 1 where these small fish contributed a striking $70 \%$ to the herbivore biomass.

\section{Macroalgae buffet assay}

A significant interaction was found between Protection and Species $\left(X^{2}=10.917, \mathrm{df}=4, p=0.0275\right)$, see Table S1 for detailed model output. For Sargassum, the consumption was more than two-fold higher in no-take zones $(66 \pm 9 \%)$ compared to the fished zones $(25 \pm 7 \% ; p=0.0064)$, with intermediate results for the marine reserves $(49 \pm 10 \%)$ that were not significantly different from the other two management types (Fig. 4). For Padina, consumption was comparably low in the fished zones $(27 \pm 7 \%)$ and consumption significantly increased over two fold in the marine reserves $(73 \pm 8 \% ; p=0.0002)$ and three-fold in the notake zones ( $81 \pm 7 \% ; p<0.0001)$; the marine reserves and no-take zones were not significantly different from each other (see Table S2 for details on Tukey's post hoc). Across all three protection zones, consumption of Padina was higher than for Sargassum (Fig. 4), and this was most evident at sites 3 and 6 (see also Fig. 6).

\section{Recorded bites}

Mass-scaled bites as recorded on RUV were dominated by a few fish species (Fig. 5). Only three species were recorded taking substantial ms-bites of Sargassum (Hipposcarus harid, Naso elegans and 
Zebrasoma desjardinii). Bites on Padina were predominantly taken by a small group of scarids (Hipposcarus harid, Scarus tricolor and Calotomus carolinus) and the unicornfish Naso elegans. The majority of the ms-bites were recorded at sites $4-6$ (Table S3), whereas only very few ms-bites were recorded at sites $1-3$ and those were mainly taken by a small territorial damselfish (Plectroglyphidodon lacrymatus). At sites $4-6$, a different species dominated at each site, with Naso elegans taking most ms-bites at site 4, Scarus tricolor dominating ms-bites at site 5 and Hipposcarus harid taking most msbites at site 6 (Table S3).

\section{Correlations}

The fraction of consumed macroalgae correlated positively with the total biomass of herbivorous fish, though seemed to level off above an herbivorous fish biomass of around $200 \mathrm{~kg} \mathrm{ha}^{-1}$ (Fig. 6a). Looking at the separate functional groups, macroalgae consumption correlated positively with the biomass of browsing herbivorous fish (Fig. 6b) and this correlation appeared mainly driven by browsers of the genus Naso (Fig. 6c). A strong positive correlation was found for grazing herbivorous fish and macroalgae consumption (Fig. $6 \mathrm{~d}$ ). The fraction of consumed macroalgae did neither correlate significantly with the biomass of scrapers (Fig. 6e) nor territorial damselfish (Fig. 6f). The abundance of grazing urchins correlated negatively with the fraction of consumed macroalgae (Fig. $6 \mathrm{~g}$ ). No statistically significant correlation was found between the fraction of consumed macroalgae and the cover of macroalgae (Fig. 6h) or hard coral cover (Fig. 6i).

\section{Discussion}

A major threat to coral reefs is the phase shift from corals towards macroalgae, promoted by eutrophication and warmer waters and exacerbated by the removal of herbivorous fish by overfishing (Hughes et al. 2007; Ledlie et al. 2007; Pratchett et al. 2014). Key browsing fish species, their impact on reefs and the relationships to fisheries management are geographically variable and still largely unknown from the East African Coast. We characterized the herbivore community and quantified their browsing pressure at six Kenyan reefs within three distinct fisheries management zones, and related realized browsing pressure to herbivore biomasses and other common reef indicators. Browsing pressure on the presented macroalgae was two-fold greater in areas with partial fishing restrictions and up to three times higher at fully protected reefs, and this higher browsing pressure correlated positively with the higher biomasses of herbivorous fish present at these protected reefs. In line with previous studies, only a select few dominant browsers were identified (Puk et al. 2016), the key species varied strongly across reefs (Cvitanovic and Bellwood 2009) and also included herbivores not specifically classified as browsers (Chong-Seng et al. 2014). Browsing pressure correlated poorly with coral cover suggesting that coraldominated reefs can persist even under low levels of browsing (Cernohorsky et al. 2015; Holbrook et al. 2016). The implication of limited browsing activity, however, is that these reefs might be impaired in their ability to absorb disturbances that stimulate macroalgal growth (Holbrook et al. 2016). Overall, our results affirm that fishing restrictions can have a strong positive influence on herbivorous fish biomass and highlight how this can be expected to increase reef resilience by supporting higher rates of browsing. 
Shifts in the herbivore community and strong reductions in key functional groups including browsing, scraping and excavating herbivores were found at the fished study sites, confirming results found at the northern Kenyan coast (Humphries et al. 2015), and potentially undermining the resilience of these reefs (Nyström et al. 2008; Holbrook et al. 2016). Herbivorous fish biomass in the no-take zones and marine reserve (except site 3 ) was comparable with worldwide averages from protected reefs (Edwards et al. 2013) and this biomass was around 10 times lower at the sites without fishing restrictions. An exception was the macroalgae-dominated study site 3 in the marine reserve, which had an equally low fish biomass as the fished reefs. At this site and at the fished reefs, no large herbivores $(>30 \mathrm{~cm})$ were recorded, indicative of severe overfishing (McClanahan et al. 2008), habitat degradation (Rogers et al. 2018) or both. The observed reductions in herbivore biomass were most striking for large-bodied and functionally important fish such as browsers, scrapers and excavators. This impact of high fishing pressure on key functional groups has been observed worldwide (Edwards et al. 2013; Humphries et al. 2014), but is remarkably severe along the East African Coast (McClanahan et al. 2008; Humphries et al. 2014). It is therefore promising that the small and recently-established community managed no-take zone of Wasini (study site 6) has been able to sidestep this trend and now boasts the highest fish biomass of all the sites studied here, despite its nearshore location (Johansson et al. 2013). Unlike other young community managed reserves in Kenya where only grazers recovered (Humphries et al. 2015), also browsers and scrapers are abundant at Wasini. Our data suggest that of all herbivorous guilds, grazers are least impacted by high fishing pressure, with 'only' a three-fold reduction of their biomass at fished sites compared to the no-take zones, conform findings of Heenan et al. (2016) in American Samoa. Sea urchins and territorial damselfish showed highest abundances in fished zones and it is likely that they benefit from reduced competition as well as reduced predation by larger fish (Ceccarelli et al. 2005; McClanahan 2008).

In line with the higher biomasses of roving herbivorous fish, the removal of macroalgae was up to 3-fold greater in the no-take zones and more than two-fold greater in marine reserves compared to the fished zones. Consumption of Sargassum in the no-take zones and marine reserves was higher than found in a previously studied community managed area in northern Kenya where only $20 \%$ was consumed in $24 \mathrm{~h}$ (Humphries et al. 2015), but somewhat lower than consumption rates (81-92\% in $24 \mathrm{~h}$ ) found at the Great Barrier Reef (Hoey and Bellwood 2010). Padina consumption fell broadly within the ranges previously found (Humphries et al. 2015; Plass-Johnson et al. 2015). It seems that despite widely varying species compositions across broad geographic scales, realized browsing pressure at unfished reefs is quite comparable (Tebbett et al. 2020), highlighting the role local drivers can play in determining browsing pressure. Interestingly, consumption at the fish-depauperate and macroalgae-dominated study site 3 was also relatively high. This result contrasts with previous studies where higher densities of macroalgae were associated with lower browsing rates, supposably through feeding dilution (ChongSeng et al. 2014) or predator avoidance (Hoey and Bellwood 2011). The combination of both low fish and urchin biomass, the absence of browsing recorded on RUV, but relatively high macroalgae consumption at this structurally-eroded and macroalgae-dominated site is indeed surprising. It should be noted, however, that the high consumption was mainly driven by removal of Padina, the macroalgae which 
appeared overall more palatable in this and other experiments (Humphries et al. 2015), compared to Sargassum, the macroalgae which dominated this reef and is most often associated with phase shifts (Hughes et al. 2007). Still, the organism responsible for the high removal of Padina at this site remains unidentified and could possibly include overlooked species such as nocturnal crabs (Francis et al. 2019). At the two fished study sites, consumption was higher compared to reports of other overfished or macroalgae-dominated reefs. For example, Sargassum sp. removal rates of only $2 \%$ in $4.5 \mathrm{~h}$ were found on macroalgae-dominated reefs in the Seychelles (Chong-Seng et al. 2014). At the heavily fished zones of this study, despite the low biomass of browsing fish, macroalgae removal is possibly still realized by small-bodied grazers and sea urchins.

The possibility that small-bodied grazers can endure high fishing pressure and control macroalgal establishment could be seen as hopeful (Cernohorsky et al. 2015; Knoester et al. 2019; Müller et al. 2021), yet there are several reasons to be cautious. First, small herbivorous fish are likely to be targeting leaves or epiphytes only, without removing the holdfasts of macroalgae (Streit et al. 2015). Second, small herbivorous fish appear more vulnerable to bleaching events and the ensuing habitat loss of branching coral (Nash et al. 2016). In addition, when bleaching events open up large areas of space, macroalgal settlement and growth is likely to overwhelm the grazing capacity of small herbivores, increasing chances of a phase shift (Williams et al. 2001). We suppose this could have happened at study site 3 during the strong 1998 El Niño (McClanahan et al. 2001), despite the implemented partial fishing restrictions (Williams et al. 2019). Lastly, while increasing numbers of sea urchins can partially compensate for the loss of herbivorous fish (McClanahan 2014), the intensity of their scraping feeding method can undermine long-term reef development through bioerosion (Carreiro-Silva and McClanahan 2001) and hinder coral settlement (Humphries et al. 2020). In addition, as illustrated by the negative correlation between sea urchin abundance and macroalgae consumption in this study, browsing pressure by urchins (at overfished reefs) appears to be relatively small compared to the browsing pressure by herbivorous fish (at protected reefs). Hence, at overfished reefs, small-bodied fish and sea urchins may partially take over the role of larger herbivorous fish in controlling macroalgal growth, but such a change in control is likely to undermine reef resilience.

The apparent limited functional redundancy of browsers at the studied protected reefs may also have implications for reef resilience, as the loss of key species can have large detrimental impacts on ecosystem functioning (Cheal et al. 2013; Nash et al. 2016). In accordance with reports from numerous preceding studies using macroalgae buffet assays, browsing in this study was dominated by a few species only (Puk et al. 2016) and with marked variation in dominant species across sites (Cvitanovic and Bellwood 2009). Naso elegans was among the dominant browsers in this study and closely-related species have been identified as dominant browsers across the Indo-Pacific (Hoey \& Bellwood, 2009; Plass-Johnson et al., 2015; Welsh \& Bellwood, 2015), highlighting the importance of this genus in macroalgal control across broad geographic scales. Browsing was not only performed by those classified as browsers and this supports several studies that suggest plasticity in functional roles exists (Bellwood et al. 2006; Chong-Seng et al. 2014; Tebbett et al. 2020). Indeed, scraping parrotfish were recorded taking substantial amounts of bites as has been found in previous studies (McClanahan et al. 1994), but are 
more likely to have been targeting epiphytes (Lefèvre and Bellwood 2011; Clements et al. 2017). Interestingly, Siganus spp. and Kyphosus spp., species frequently identified as dominant browsers at the Central Indo-Pacific and Great Barrier Reef (Michael et al. 2013; Puk et al. 2016) were not recorded biting in this study despite their presence in nearby seagrass habitat and at the reef crest. Instead, Siganus spp. in the Western Indian Ocean have been shown to target more delicate and turf algae (Humphries et al. 2015; Ebrahim et al. 2020). Kyphosus spp., situated higher in water column, might have been feeding on drifting algae instead (Carpenter 1986). Altogether, these results align with other browsing studies in the Indo-Pacific in that they identify only a select and sometimes surprising group of species responsible for macroalgal removal from the diverse assemblage of potential browsers present. This variability may in part explain the finding that the reef with the highest herbivore biomass in this study did not bolster the highest browsing pressure, and especially consumption of Sargassum was relatively low here. Thus, in addition to the biomass of herbivores present, realized browsing pressure is likely also depending on many more factors such as spatial restrictions (Puk et al. 2016), behavioural variation (Bennett and Bellwood 2011) as well as temporal variation (Lefèvre and Bellwood 2011; Seah et al. 2021).

The variation in browsing pressure found can be indicative of divergent resilience between the studied reefs and their fisheries management (Nyström et al. 2008). Holbrook et al. (2016) experimentally identified a coral to macroalgae tipping point when herbivore biomass dropped below about $50 \mathrm{~kg} \mathrm{ha}^{-1}$ in Moorea. This experimental biomass threshold corroborates field observations from reefs in Indonesia, where a lack of macroalgal removal was observed at herbivorous fish biomass levels below $50 \mathrm{~kg} \mathrm{ha}^{-1}$ (Plass-Johnson et al. 2015). Three of the six Kenyan reefs included in the current study harboured an herbivore biomass that was just above this threshold. On two of these reefs, coral is still dominant over macroalgae. This finding is in agreement with data from Singaporean (Bauman et al. 2017), Indian (Cernohorsky et al. 2015) and Indonesian (Plass-Johnson et al. 2015) reefs, where macroalgae removal and coral dominance are still realized with herbivorous fish biomasses as low as $80 \mathrm{~kg} \mathrm{ha}^{-1}$. Nevertheless, reefs like these might be pushed to macroalgae dominance through an external disturbance such as bleaching (Williams et al. 2001). The minimum herbivore biomass needed to absorb such increasingly common disturbances remains unknown for the Indo-Pacific (Roff and Mumby 2012), but could possibly lie around $200 \mathrm{~kg} \mathrm{ha}^{-1}$ at our study sites as above this threshold browsing pressure was found to level off. In the marine reserve, a coral-dominated and a macroalgae-dominated reef co-exist under roughly equal browsing pressure. This co-existence could be indicative of alternative steady states (Holbrook et al. 2016) and illustrates that shifts to alternative stable states can be difficult to reverse even when ambient browsing pressure is relatively high (Schmitt et al. 2019). In such cases, the protection of herbivorous fish could be reinforced by removing macroalgae manually in an effort to push the ecosystem back to coral dominance (Ceccarelli et al. 2018; Williams et al. 2019). More effective, however, would be to keep herbivore levels well above phase-shift thresholds and prevent macroalgal dominance in the first place (Anthony et al. 2015). Our results indicate that fisheries management through marine reserves and notake zones in particular, even small-scale and community-managed, have the potential to safeguard the diversity and biomass of functionally important herbivorous fish. Following effective management, a high level of macroalgal control is realized as large-bodied browsing and scraping fish seem to benefit 
markedly from fisheries protection. Although gains in browsing pressure appear to level off with increasing herbivore biomass and reasonable levels of browsing were still realized at fished study sites, the long-term resilience of these fished reefs is uncertain given the eroding nature of urchin browsing (Carreiro-Silva and McClanahan 2001), the high susceptibility of small-bodied herbivorous fish to coral loss (Nash et al. 2016) and their limited capacity to control sudden increases in macroalgae (Williams et al. 2001; Streit et al. 2015). Therefore, we recommend to continue the establishment of a network of community managed no-take zones to allow for the recovery of herbivorous fish biomass well above potential phase-shift thresholds, increase ecosystem resilience, promote local stewardship and move towards sustainable use of coral reefs (Topor et al. 2019). Such local management could help restore and maintain coral dominance and provide heightened resilience against large-scale disturbances during the Anthropocene.

\section{Statements And Declarations}

\section{Author's contributions:}

The study was designed by EGK, VEP and RO; the field work was logistically enabled by SOS and carried out by EGK and VEP; the data analysis was conducted by EGK; the paper was written and approved by EGK, VEP, RO, AJM and SOS.

\section{Conflict of interest:}

The authors declare that they have no conflicts of interest.

\section{Availability of data and material:}

The datasets analysed for this study are available in the Mendeley Data repository at: [link to be created]. The code used for analysis is available as a Github repository on: https://github.com/ewoutknoester/HerbivoryBrowsing

\section{Funding:}

This research was supported through internal funding schemes of the Marine Animal Ecology Group at Wageningen University and Research.

\section{Ethical approval:}

No approval of research ethics committees was required for this observational study. Applicable international guidelines for monitoring on coral reefs were followed.

\section{Acknowledgements:}

We would like to acknowledge the Kenya Wildlife Service and their Strategic Adaptive Management through which collaborative data collection in Kisite-Mpunguti Marine National Park was possible. We 
thank both the Mkwiro and Wasini Beach Management Units for the collaboration in their community marine areas. We thank Gerrit Gort for his advice on mixed-effects modelling. We thank the reviewers for their time taken to provide valuable input.

\section{References}

1. Anthony KRN, Marshall PA, Abdulla A, Beeden R, Bergh C, Black R, Eakin CM, Game ET, Gooch M, Graham NAJ, Green AL, Heron SF, Van Hooidonk RJ, Knowland CA, Mangubhai S, Marshall N, Maynard JA, McGinnity P, Mcleod E, Mumby PJ, Nyström M, Obura DO, Oliver J, Possingham HP, Pressey RL, Rowlands GP, Tamelander J, Wachenfeld D, Wear S (2015) Operationalizing resilience for adaptive coral reef management under global environmental change. Glob Chang Biol 21:48-61. doi: $10.1111 /$ gcb. 12700

2. Bauman AG, Hoey AS, Dunshea G, Feary DA, Low J, Todd PA (2017) Macroalgal browsing on a heavily degraded, urbanized equatorial reef system. Sci Rep 7:1-8. doi: 10.1038/s41598-017-088733

3. Bellwood DR, Hughes TP, Hoey AS (2006) Sleeping functional group drives coral-reef recovery. Curr Biol 16:2434-2439. doi: 10.1016/j.cub.2006.10.030

4. Bennett S, Bellwood DR (2011) Latitudinal variation in macroalgal consumption by fishes on the Great Barrier Reef. Mar Ecol Prog Ser 426:241-252. doi: 10.3354/meps09016

5. Bohnsack JA, Bannerot SP (1986) A stationary visual census technique for quantitatively assessing community structure of coral reef fishes. NOAA Tech Rep NMFS 41:21.

6. Brandl SJ, Bellwood DR (2014) Individual-based analyses reveal limited functional overlap in a coral reef fish community. J Anim Ecol 83:661-670. doi: 10.1111/1365-2656.12171

7. Brooks ME, Kristensen K, van Benthem KJ, Magnusson A, Berg CW, Nielsen A, Skaug HJ, Mächler M, Bolker BM (2017) glmmTMB balances speed and flexibility among packages for zero-inflated generalized linear mixed modeling. R J 9:378-400. doi: 10.32614/rj-2017-066

8. Carpenter RC (1986) Partitioning herbivory and its effects on coral reef algal communities.

9. Carreiro-Silva M, McClanahan TR (2001) Echinoid bioerosion and herbivory on Kenyan coral reefs: the role of protection from fishing. J Exp Mar Bio Ecol 262:133-153. doi: 10.1016/S00220981(01)00288-X

10. Ceccarelli DM, Jones GP, McCook LJ (2005) Foragers versus farmers: contrasting effects of two behavioural groups of herbivores on coral reefs. Oecologia 145:445-53. doi: 10.1007/s00442-0050144-y

11. Ceccarelli DM, Loffler Z, Bourne DG, Al Moajil-Cole GS, Boström-Einarsson L, Evans-Illidge E, Fabricius KE, Glasl B, Marshall PA, Mcleod IM, Read M, Schaffelke B, Smith AK, Jorda GT, Williamson DH, Bay L (2018) Rehabilitation of coral reefs through removal of macroalgae: state of knowledge and considerations for management and implementation. Restor Ecol 26:827-838. doi:

$10.1111 /$ rec. 12852 
12. Cernohorsky NH, McClanahan TR, Babu I, Horsák M (2015) Small herbivores suppress algal accumulation on Agatti atoll, Indian Ocean. Coral Reefs 34:1023-1035. doi: 10.1007/s00338-0151331-x

13. Cheal AJ, Emslie MJ, Macneil MA, Miller I, Sweatman HPA (2013) Spatial variation in the functional characteristics of herbivorous fish communities and the resilience of coral reefs. Ecol Appl 23:174188.

14. Chong-Seng KM, Nash KL, Bellwood DR, Graham NAJ (2014) Macroalgal herbivory on recovering versus degrading coral reefs. Coral Reefs 33:409-419. doi: 10.1007/s00338-014-1134-5

15. Clements KD, German DP, Piché J, Tribollet AD, Choat JH (2017) Integrating ecological roles and trophic resources on coral reefs: multiple lines of evidence identify parrotfishes as microphages. Biol J Linn Soc 120:729-751. doi: 10.1111/bij.12914

16. Cvitanovic C, Bellwood DR (2009) Local variation in herbivore feeding activity on an inshore reef of the Great Barrier Reef. Coral Reefs 28:127-133. doi: 10.1007/s00338-008-0433-0

17. Douma JC, Weedon JT (2019) Analysing continuous proportions in ecology and evolution: a practical introduction to beta and Dirichlet regression. Methods Ecol Evol 10:1412-1430. doi: 10.1111/2041-210X.13234

18. Ebrahim A, Martin TSH, Mumby PJ, Olds AD, Tibbetts IR (2020) Differences in diet and foraging behaviour of commercially important rabbitfish species on coral reefs in the Indian Ocean. Coral Reefs. doi: 10.1007/s00338-020-01918-6

19. Edwards CB, Friedlander AM, Green AG, Hardt MJ, Sala E, Sweatman HPA, Williams ID, Zgliczynski B, Sandin SA, Smith JE (2013) Global assessment of the status of coral reef herbivorous fishes: evidence for fishing effects. Proc R Soc B Biol Sci 281:7-11.

20. Fox J, Weisberg S (2018) An R companion to applied regression. Sage publications

21. Francis FT, Filbee-Dexter K, Yan HF, Côté IM (2019) Invertebrate herbivores: overlooked allies in the recovery of degraded coral reefs? Glob Ecol Conserv 17:1-11. doi: 10.1016/j.gecco.2019.e00593

22. Froese R, Pauly D (2015) FishBase. www.fishbase.org. Accessed 3 Jan 2015

23. Green AL, Bellwood DR (2009) Monitoring functional groups of herbivorous reef fishes as indicators of coral reef resilience: a practical guide for coral reef managers in the Asia Pacific region. IUCN, Gland, Switzerland

24. Hartig F (2021) DHARMa: residual diagnostics for hierarchical (multi-level/mixed) regression models.

25. Heenan A, Williams ID (2013) Monitoring herbivorous fishes as indicators of coral reef resilience in American Samoa. PLoS One. doi: 10.1371/journal.pone.0079604

26. Heenan A, Hoey AS, Williams GJ, Williams ID (2016) Natural bounds on herbivorous coral reef fishes. Proc R Soc B Biol Sci. doi: 10.1098/rspb.2016.1716

27. Hill J, Wilkinson C (2004) Methods for ecological monitoring of coral reefs. Townsville

28. Hoey AS, Bellwood DR (2009) Limited functional redundancy in a high diversity system: single species dominates key ecological process on coral reefs. Ecosystems 12:1316-1328. doi: 
10.1007/s10021-009-9291-z

29. Hoey AS, Bellwood DR (2010) Among-habitat variation in herbivory on Sargassum spp. on a midshelf reef in the northern Great Barrier Reef. Mar Biol 157:189-200. doi: 10.1007/s00227-009-1309-8

30. Hoey AS, Bellwood DR (2011) Suppression of herbivory by macroalgal density: a critical feedback on coral reefs? Ecol Lett 14:267-273. doi: 10.1111/j.1461-0248.2010.01581.x

31. Holbrook SJ, Schmitt RJ, Adam TC, Brooks AJ (2016) Coral reef resilience, tipping points and the strength of herbivory. Sci Rep 6:1-11. doi: 10.1038/srep35817

32. Hughes TP (1994) Catastrophes, phase shifts, and large-scale degradation of a Caribbean coral reef. Science (80- ) 265:1547-1551.

33. Hughes TP, Rodrigues MJ, Bellwood DR, Ceccarelli DM, Hoegh-Guldberg O, McCook LJ, Moltschaniwskyj N, Pratchett MS, Steneck RS, Willis BL (2007) Phase shifts, herbivory, and the resilience of coral reefs to climate change. Curr Biol 17:360-365. doi: 10.1016/j.cub.2006.12.049

34. Humphries AT, McClanahan TR, McQuaid CD (2014) Differential impacts of coral reef herbivores on algal succession in Kenya. Mar Ecol Prog Ser 504:119-132. doi: 10.3354/meps10744

35. Humphries AT, McQuaid CD, McClanahan TR (2015) Context-dependent diversity-effects of seaweed consumption on coral reefs in Kenya. PLoS One. doi: 10.1371/journal.pone.0144204

36. Humphries AT, McClanahan TR, McQuaid CD (2020) Algal turf consumption by sea urchins and fishes is mediated by fisheries management on coral reefs in Kenya. Coral Reefs. doi: 10.1007/s00338-020-01943-5

37. Johansson CL, van de Leemput IA, Depczynski M, Hoey AS, Bellwood DR (2013) Key herbivores reveal limited functional redundancy on inshore coral reefs. Coral Reefs 32:963-972. doi: 10.1007/s00338-013-1044-y

38. Knoester EG, Murk AJ, Osinga R (2019) Benefits of herbivorous fish outweigh costs of corallivory in coral nurseries placed close to a Kenyan patch reef. Mar Ecol Prog Ser 611:143-155. doi: 10.3354/meps12869

39. Ladd MC, Miller MW, Hunt JH, Sharp WC, Burkepile DE (2018) Harnessing ecological processes to facilitate coral restoration. Front Ecol Environ 16:239-247. doi: 10.1002/fee.1792

40. Ledlie N, Graham NAJ, Bythell SK, Wilson SK, Jennings N, Polunin NVC, Hardcastle J (2007) Phase shifts and the role of herbivory in the resilience of coral reefs. Coral Reefs 26:641-653. doi: $10.1007 / \mathrm{s} 00338-007-0230-1$

41. Lefcheck JS, BrandI SJ, Innes-Gold AA, Steneck RS, Torres RE, Rasher DB (2019) Tropical fish diversity enhances coral reef functioning across multiple scales. Sci Adv. doi: 10.3389/fevo.2019.00303

42. Lefèvre CD, Bellwood DR (2011) Temporal variation in coral reef ecosystem processes: herbivory of macroalgae by fishes. Mar Ecol Prog Ser 422:239-251. doi: 10.3354/meps08916

43. Lenth R (2020) emmeans: Estimated Marginal Means, aka Least-Squares Means. 
44. McCauley DJ, Pinsky ML, Palumbi SR, Estes JA, Joyce FH, Warner RR (2015) Marine defaunation: animal loss in the global ocean. Science (80-). doi: 10.1126/science. 1255641

45. McClanahan TR (2008) Response of the coral reef benthos and herbivory to fishery closure management and the 1998 ENSO disturbance. Oecologia 155:169-177. doi: 10.1007/s00442-0070890-0

46. McClanahan TR (2014) Recovery of functional groups and trophic relationships in tropical fisheries closures. Mar Ecol Prog Ser 497:13-23. doi: 10.3354/meps10605

47. McClanahan TR, Nugues MM, Mwachireya S (1994) Fish and sea urchin herbivory and competition in Kenyan coral reef lagoons: the role of reef management. J Exp Mar Bio Ecol 184:237-254. doi: 10.1016/0022-0981(94)90007-8

48. McClanahan TR, Muthiga NA, Mangi SC (2001) Coral and algal changes after the 1998 coral bleaching: interaction with reef management and herbivores on Kenyan reefs. Coral Reefs 19:380391. doi: $10.1007 / \mathrm{s} 003380000133$

49. McClanahan TR, Hicks CC, Darling ES (2008) Malthusian overfishing and efforts to overcome it on Kenyan coral reefs. Ecol Appl 18:1516-1529. doi: 10.1890/07-0876.1

50. Michael PJ, Hyndes GA, Vanderklift MA, Vergés A (2013) Identity and behaviour of herbivorous fish influence large-scale spatial patterns of macroalgal herbivory in a coral reef. Mar Ecol Prog Ser 482:227-240. doi: 10.3354/meps 10262

51. Müller M, Staab CFK, Puk LD, Schoenig EM, Ferse SCA, Wild C (2021) The rabbitfish siganus virgatus as key macroalgae browser in coral reefs of the gulf of Thailand. Diversity 13:1-18. doi: $10.3390 / \mathrm{d} 13030123$

52. Nash KL, Graham NAJ, Jennings S, Wilson SK, Bellwood DR (2016) Herbivore cross-scale redundancy supports response diversity and promotes coral reef resilience. J Appl Ecol 53:646-655. doi: 10.1111/1365-2664.12430

53. Norström A V., Nyström M, Lokrantz J, Folke CS (2009) Alternative states on coral reefs: beyond coral - macroalgal phase shifts. Mar Ecol Prog Ser 376:295-306. doi: 10.3354/meps07815

54. Nyström M, Graham NAJ, Lokrantz J, Norström A V. (2008) Capturing the cornerstones of coral reef resilience: linking theory to practice. Coral Reefs 27:795-809. doi: 10.1007/s00338-008-0426-z

55. Plass-Johnson JG, Ferse SCA, Jompa J, Wild C, Teichberg M (2015) Fish herbivory as key ecological function in a heavily degraded coral reef system. Limnol Oceanogr 60:1382-1391. doi: 10.1002/Ino.10105

56. Pratchett MS, Hoey AS, Wilson SK (2014) Reef degradation and the loss of critical ecosystem goods and services provided by coral reef fishes. Curr Opin Environ Sustain 7:37-43. doi: 10.1016/j.cosust.2013.11.022

57. Puk LD, Ferse SCA, Wild C (2016) Patterns and trends in coral reef macroalgae browsing: a review of browsing herbivorous fishes of the Indo-Pacific. Rev Fish Biol Fish 26:53-70. doi: 10.1007/s11160015-9412-z

58. R Core Team (2020) R: A Language and Environment for Statistical Computing. 
59. Roff G, Mumby PJ (2012) Global disparity in the resilience of coral reefs. Trends Ecol Evol 27:404413. doi: $10.1016 /$ j.tree.2012.04.007

60. Rogers A, Blanchard JL, Mumby PJ (2018) Fisheries productivity under progressive coral reef degradation. J Appl Ecol 55:1041-1049. doi: 10.1111/1365-2664.13051

61. Schmitt RJ, Holbrook SJ, Davis SL, Brooks AJ, Adam TC (2019) Experimental support for alternative attractors on coral reefs. Proc Natl Acad Sci 116:4372-4381. doi: 10.1073/pnas.1812412116

62. Seah JCL, Bauman AG, Todd PA (2021) Temporal variation in macroalgal removal: insights from an impacted equatorial coral reef system. Mar Biol 168:1-12. doi: 10.1007/s00227-020-03806-7

63. Streit RP, Hoey AS, Bellwood DR (2015) Feeding characteristics reveal functional distinctions among browsing herbivorous fishes on coral reefs. Coral Reefs 34:1037-1047. doi: 10.1007/s00338-0151322-y

64. Sully S, Burkepile DE, Donovan MK, Hodgson G, van Woesik R (2019) A global analysis of coral bleaching over the past two decades. Nat Commun 10:1-5. doi: 10.1038/s41467-019-09238-2

65. Tebbett SB, Hoey AS, Depczynski M, Wismer S, Bellwood DR (2020) Macroalgae removal on coral reefs: realised ecosystem functions transcend biogeographic locations. Coral Reefs 39:203-214. doi: 10.1007/s00338-019-01874-w

66. Topor ZM, Rasher DB, Duffy JE, Brandl SJ (2019) Marine protected areas enhance coral reef functioning by promoting fish biodiversity. Conserv Lett 12:1-9. doi: 10.1111/conl.12638

67. Welsh JQ, Bellwood DR (2015) Simulated macro-algal outbreak triggers a large-scale response on coral reefs. PLoS One. doi: 10.1371/journal.pone.0132895

68. Williams ID, Polunin NVC, Hendrick VJ (2001) Limits to grazing by herbivorous fishes and the impact of low coral cover on macroalgal abundance on a coral reef in Belize. Mar Ecol Prog Ser 222:187196.

69. Williams ID, Kindinger TL, Couch CS, Walsh WJ, Minton D, Oliver TA (2019) Can herbivore management increase the persistence of Indo-Pacific coral reefs? Front Mar Sci 6:1-15. doi: $10.3389 /$ fmars.2019.00557

\section{Figures}




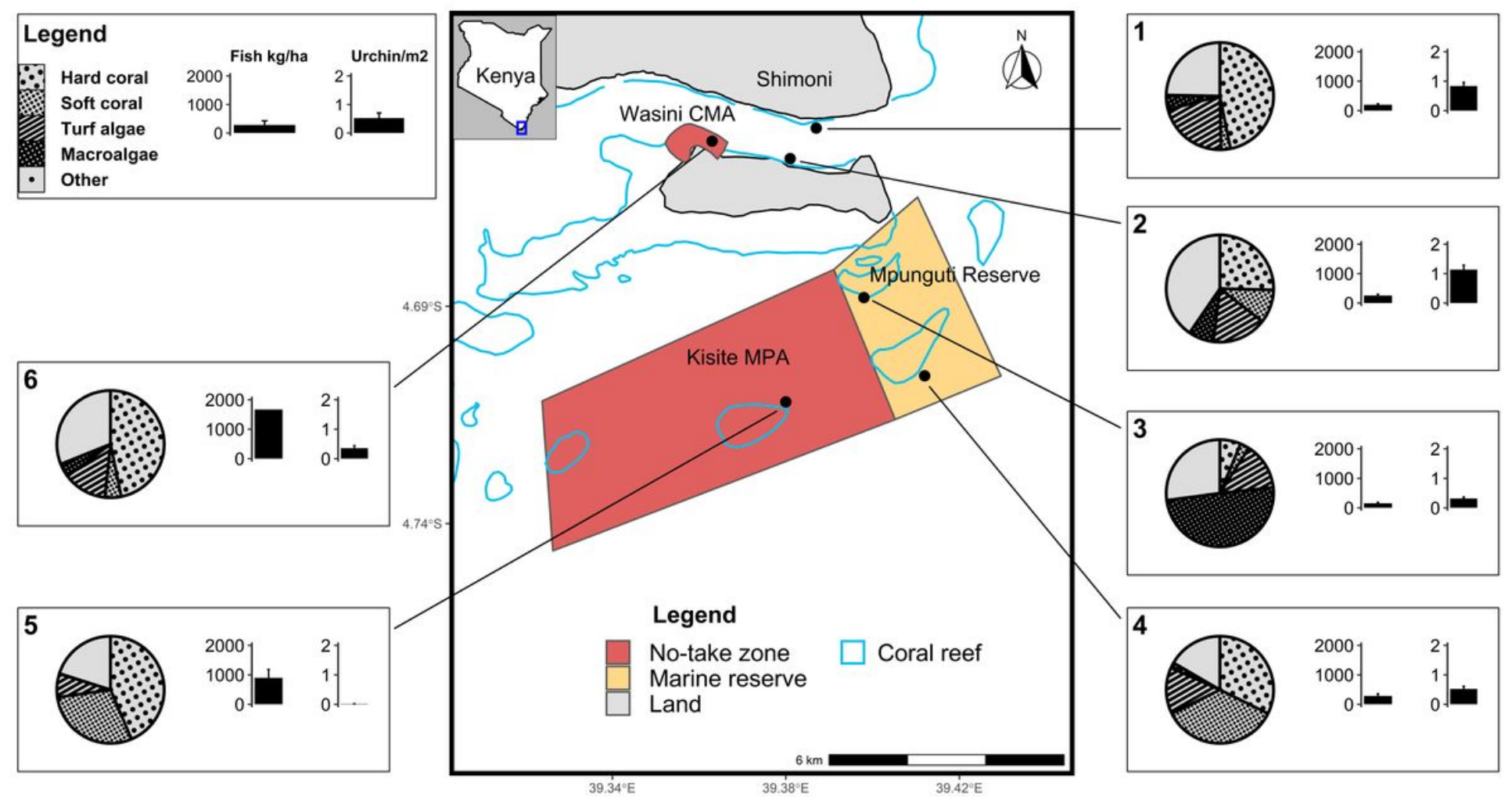

Figure 1

Map of Kenya showing study area (insert) and detailed map showing the six study sites. Three different fisheries management zones can be identified: unrestricted fished zone (unshaded) including sites $1 \& 2$, the Mpunguti Marine Reserve where traditional fishing is allowed (shaded orange) encompassing sites 3 \& 4 and no-take zones (shaded red) covering sites 5 (Kisite Marine National Park) \& 6 (Wasini Community Managed Area). Boxes shows additional information for each study site on benthic cover, total fish biomass and sea urchin abundance. Bars represent means \pm standard error $(n=10$ for benthic surveys and $n=11-15$ for fish surveys). Credit to $\mathrm{H}$. Mwamlavya for compiling the figure 

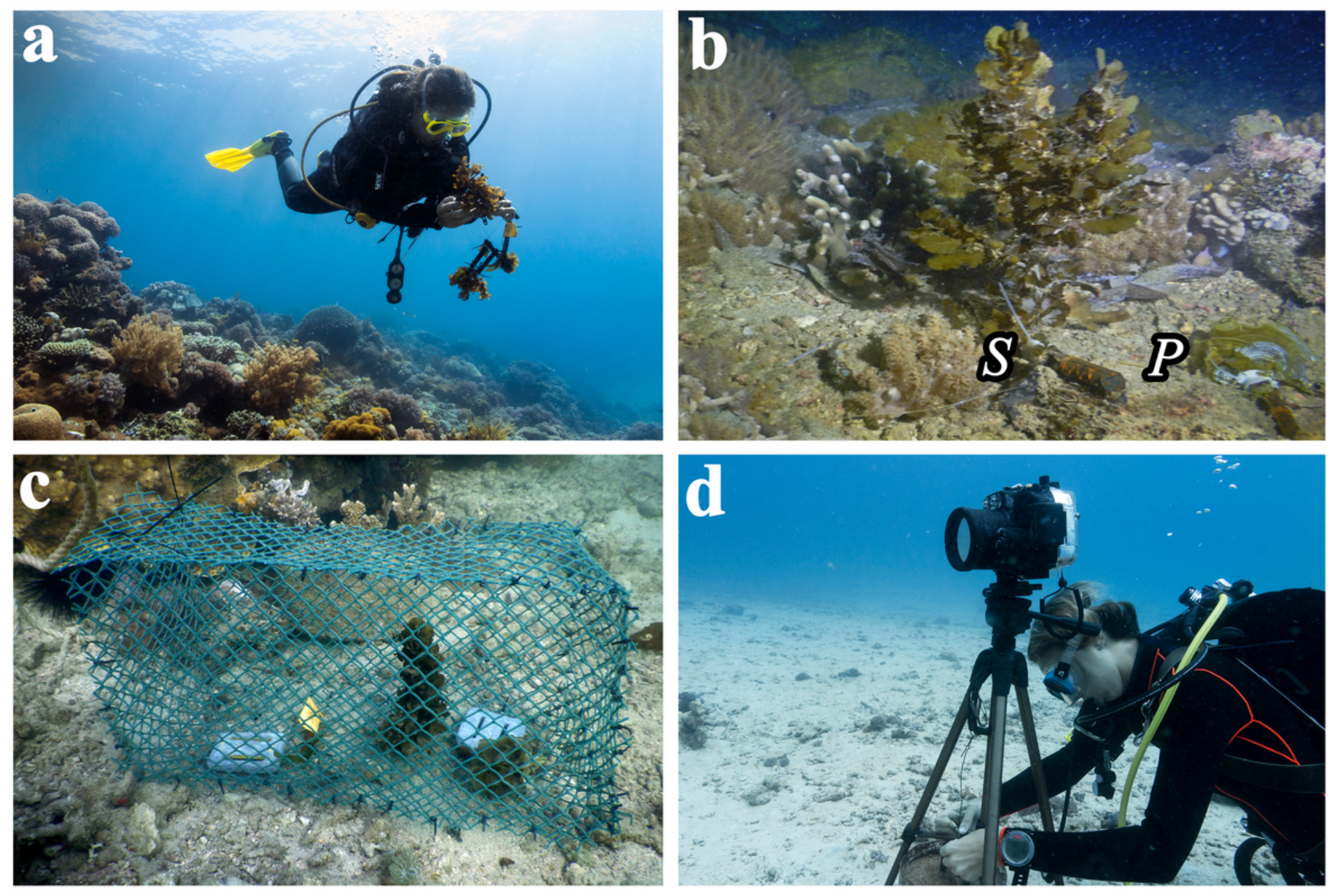

\section{Figure 2}

Experimental setup of the buffet assay. $\mathbf{a}$ Diver placing macroalgae on the reef. $\mathbf{b}$ Close-up of one assay

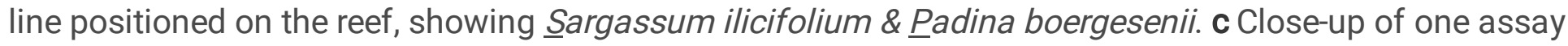
in the control cage. $\mathbf{d}$ Diver preparing the remote underwater video recording. Source a-d: EGK 


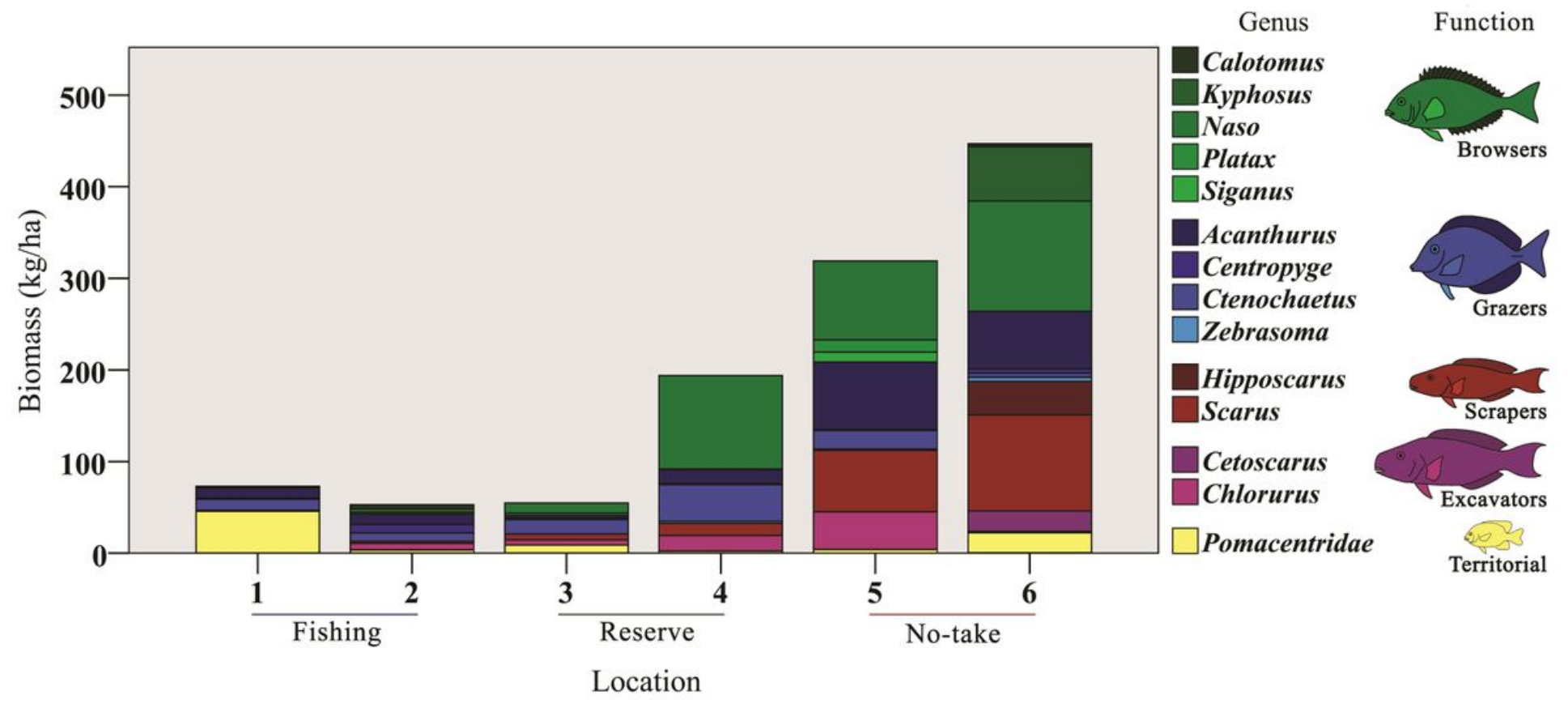

Figure 3

Herbivorous fish biomass $\left(\mathrm{kg} \mathrm{ha}^{-1}\right)$ per study site and type of fisheries management. Average biomass ( $\mathrm{n}$ $=11-15$ fish surveys) is stacked by genus. Colours indicate functional groups: browsers (green), grazers (blue), scrapers (red), excavators (purple) and territorial damselfish (yellow), and shades further identify each genus

Sargassum

Padina

1.0

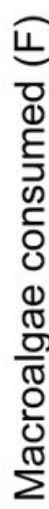

0.0

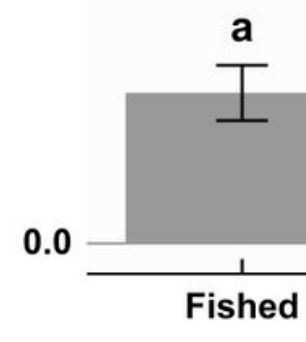

Fished

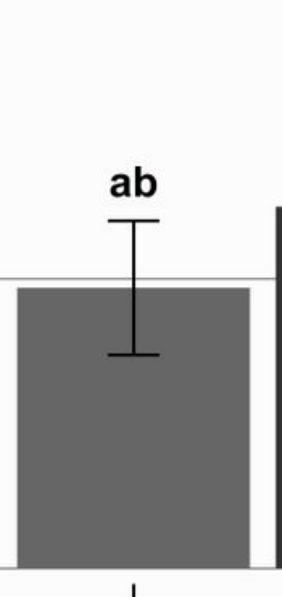

Reserve
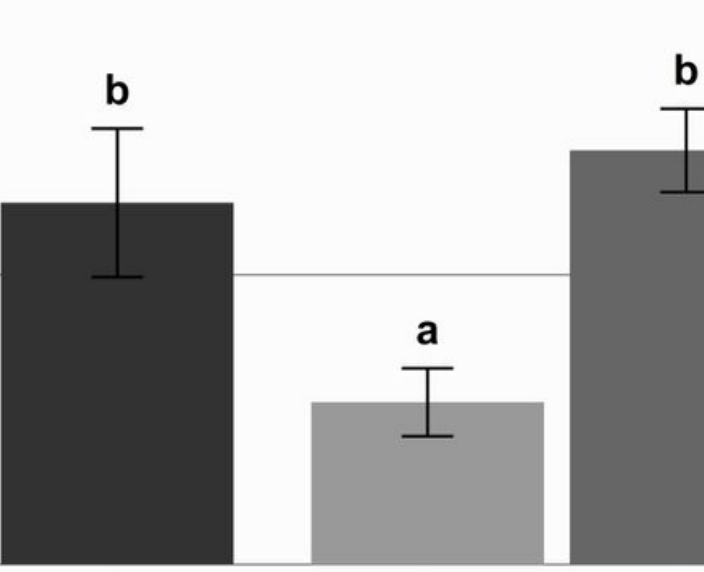

b

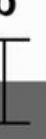

0.5

\section{Reserve}

No-take

Fished

Reserve

No-take

Fisheries management

Figure 4 
Fraction of macroalgal biomass consumed in $24 \mathrm{~h}(\mathrm{~F})$ for both Sargassum ilicifolium and Padina boergesenii, split between three types of fisheries management. Bars present mean \pm standard error $(n=$ 10). Letters above indicate significant differences $(p<0.05)$ between fisheries management for each macroalgae

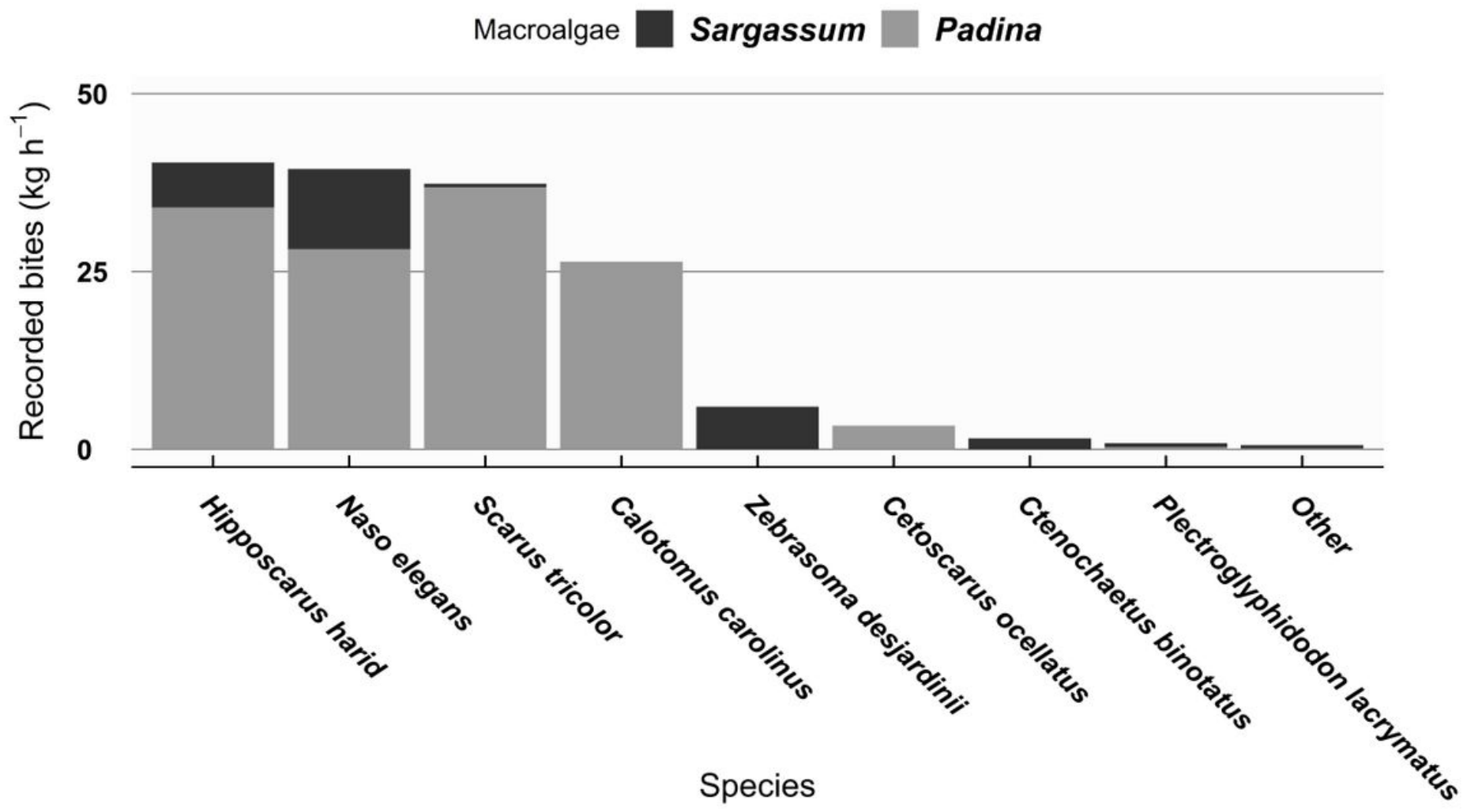

Figure 5

Recorded mass-scaled bites $\left(\mathrm{kg} \mathrm{h}^{-1}\right)$ on presented macroalgae by fish species recorded on remote underwater video, summed across all study sites 


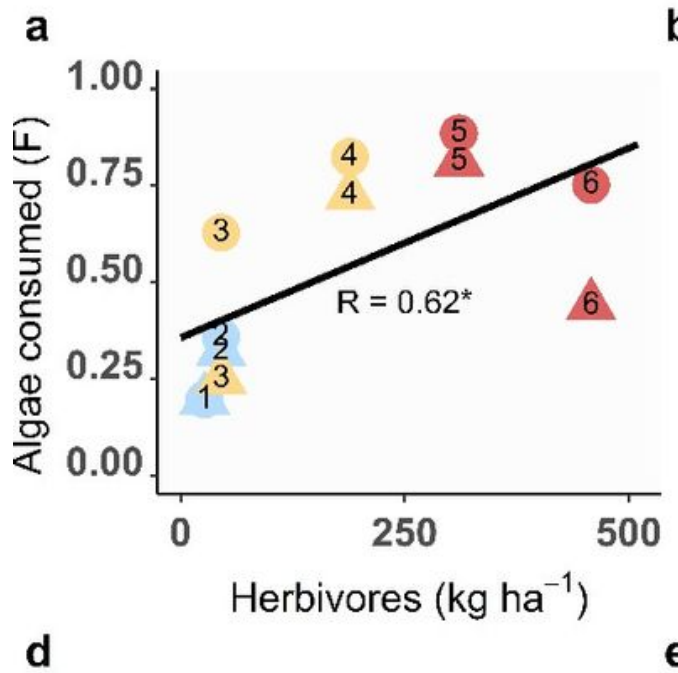

b

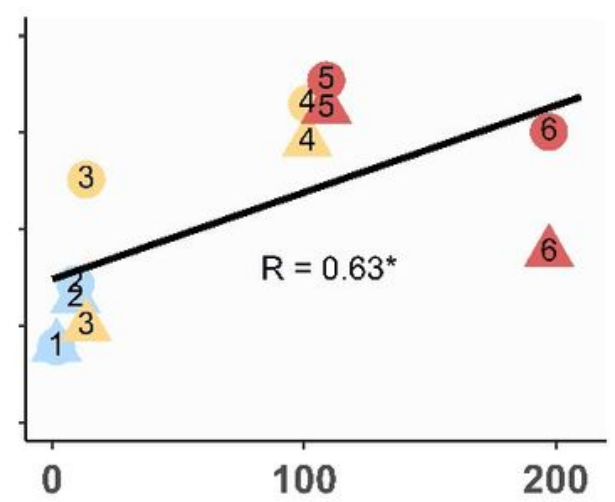

C

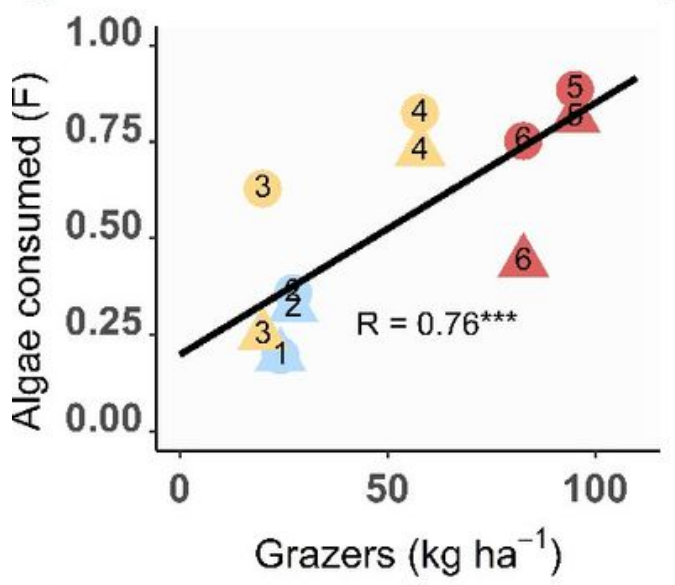

e

Browsers $\left(\mathrm{kg} \mathrm{ha}^{-1}\right)$
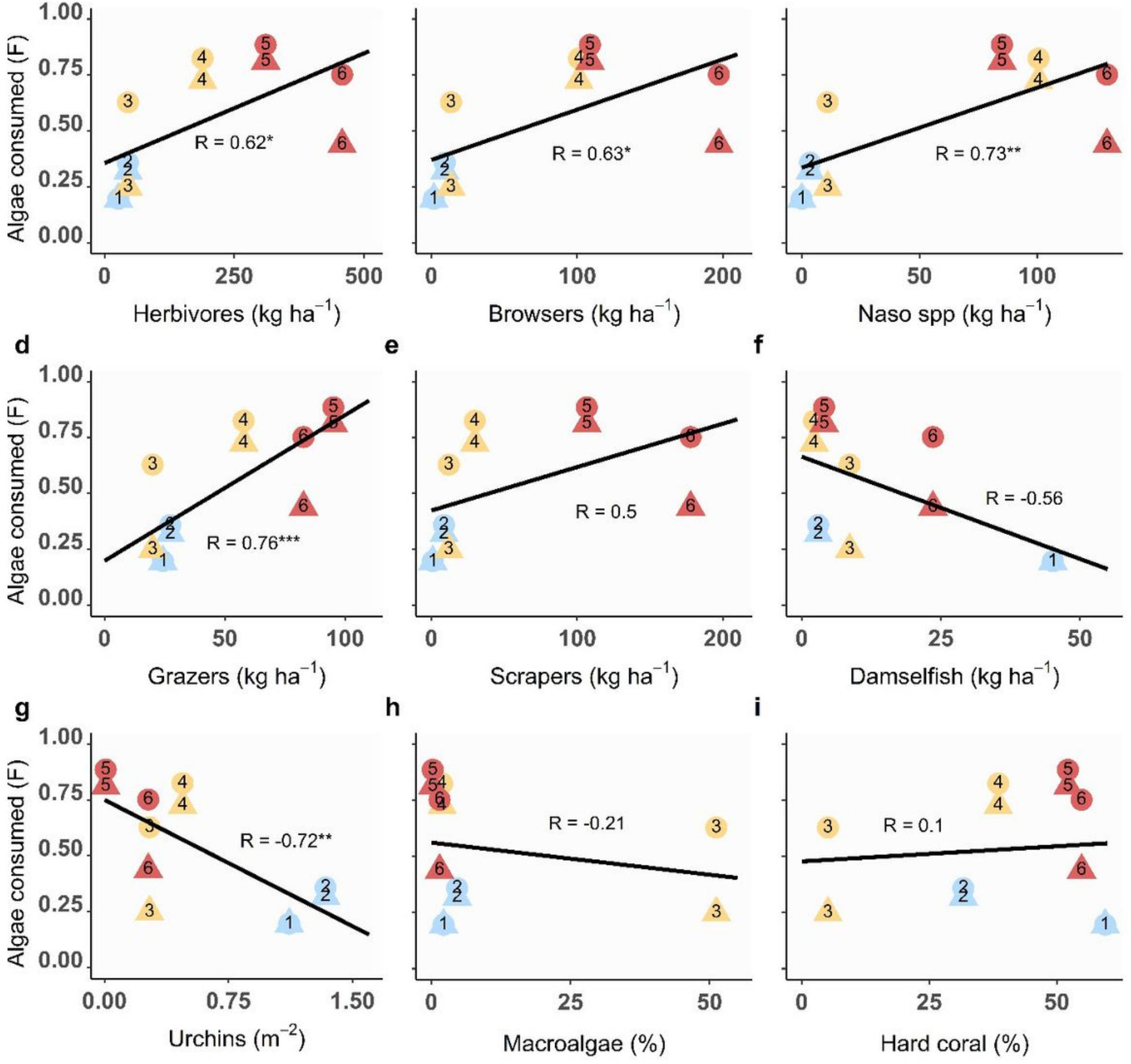

Protection Fishing

Reserve No-take Species

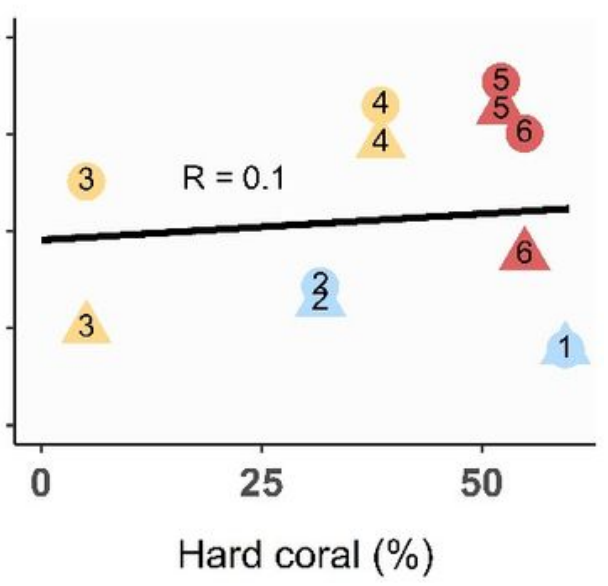

Figure 6

Correlations between the fraction of macroalgal biomass consumed and a the total biomass of herbivorous fish $\mathbf{b}$ the biomass of browsing herbivorous fish and $\mathbf{c}$ browsers of the genus Naso specifically, $\mathbf{d}$ grazing herbivorous fish biomass, e scraping herbivorous fish biomass, $\mathbf{f}$ territorial damselfish biomass, $\mathbf{g}$ urchin abundance, $\mathbf{h}$ macroalgal cover and $\mathbf{i}$ hard coral cover. Linear trend lines are added with their associated Pearson correlation coefficient (R) and significance indicated $\left({ }^{*} p<0.05,{ }^{*} p\right.$ 
$\left.<0.01,{ }^{\star \star \star} p<0.001\right)$. Averages for both Sargassum and Padina are shown, but because patterns were very similar for both macroalgae data was pooled for the correlations

\section{Supplementary Files}

This is a list of supplementary files associated with this preprint. Click to download.

- Knoesteretal2022SupplementarymaterialMarineBiology.docx 